INDO GLOBAL JOURNAL OF

PHARMACEUTICAL SCIENCES

ISSN 2249- 1023

\title{
Effect of Conjoint Use of Bioactive Phosphocompost and Chemical Fertilizers on Plant Growth Properties, Soil Properties \& Microbial Properties under Pea Cropping
}

\author{
Deepshikha Thakur ${ }^{1}$, Rajesh Kaushal ${ }^{2}$, Vineet Shyam ${ }^{2}$ \\ ${ }^{1}$ Chitkara University, Punjab, India \\ ${ }^{2}$ Dr. Y S Parmar University of Horticulture and Forestry, Nauni, Solan, H.P., India
}

Address for Correspondance: Deepshikha Thakur, deepshikhathakur212@gmail.com ; Rajesh Kaushal, drrkaushal@rediffmail.com ; Vineet Shyam, vineet.shyam@gmail.com

Keywords

Bioactive;

Phosphocompost;

Pea; Microbial;

Soil; Enzyme.

\begin{abstract}
The field experiment was conducted at Dr.Y S P UHF, Nauni, Solan, (H.P.), to study the effect of conjoint use of bioactive phosphocompost and recommended dose of chemical fertilizers on various plant, soil and microbiological parameters under pea crop. In the experiment, the bioactive phosphocompost $(0.98 \%, 2.24 \%, 0.81 \% \mathrm{~N}, \mathrm{P}, \mathrm{K}$ respectively), was used in 6 different combinations with the chemical fertilizers. Out of 6 treatment combinations, treatment T3 (conjoint use of $75 \%$ recommended dose of chemical fertilizers and $25 \%$ phosphocompost) proved to be significantly superior in increasing the various plant parameters such as shoot length $(76.25 \mathrm{~cm})$, root length $(22.25 \mathrm{~cm})$, total plant biomass $(40.78 \mathrm{q} / \mathrm{ha})$, green pod yield ( $219 \mathrm{q} / \mathrm{ha}$ ) etc., over control. The significantly higher content of $\mathrm{N}(4.54 \%), \mathrm{P}(0.55 \%)$ and $\mathrm{K}$ $(2.39 \%)$ was again recorded in T3 treatment. Although, significantly higher organic matter $(1.32 \%)$, CEC $(44.37 \mathrm{c} \mathrm{mol}(\mathrm{p}+) / \mathrm{kg})$, available $\mathrm{P}(143.33 \mathrm{~kg} / \mathrm{h})$ and soil enzyme activities were recorded in $\mathrm{T} 6$ treatment $(100$ $\%$ Phosphocompost). Various microbiological properties like microbial biomass, microbial activity, total microbial count, $\mathrm{P}$ solubilizer count, Rhizobium count and siderophore producers were also recorded highest in T6 treatment. The study has come out with a conclusion that the conjoint use of $75 \%$ recommended dose of chemical fertilizers and $25 \%$ phosphocompost, increases the plant growth and yield significantly, besides improving the soil physico-chemical and microbiological properties. (C) 2016 iGlobal Research and Publishing Foundation. All rights reserved.
\end{abstract}

Conference Proceedings: International Conference on Advances in Plant and Microbial Biotechnology (PMB2017); JIIT, Noida: February 02-04, 2017

Indo Global Journal of Pharmaceutical Sciences( ISSN 22491023 ; CODEN- IGJPAI; NLM ID: 101610675) indexed and abstracted in EMBASE(Elsevier), SCIRUS(Elsevier),CABI, CAB Abstracts, Chemical Abstract Services(CAS), American Chemical Society(ACS), Index Copernicus, EBSCO, DOAJ, Google Scholar and many more. For further details, visit http://iglobaljournal.com 